\title{
TINJAUAN RUANG TERBUKA HIJAU DI KAMPUS POLITEKNIK NEGERI JAKARTA
}

\author{
Suripto $^{(1)}$, Melatifani ${ }^{(2)}$, Muhammad Iqbal Pratama ${ }^{(3)}$ \\ IPengajar Jurusan Teknik Sipil, Politeknik Negeri Jakarta, Kampus UI Depok 16425, Telp. 021-7270036, \\ email: toriptop@gmail.com \\ ${ }^{2}$ Alumni Jurusan Teknik Sipil, Politeknik Negeri Jakarta, Kampus UI Depok 16425, Telp. 021-7270036, \\ email:melatifani@gmail.com \\ ${ }^{3}$ Alumni Jurusan Teknik Sipil, Politeknik Negeri Jakarta, Kampus UI Depok 16425, Telp. 021-7270036, \\ email: mriqbaliopsrb@gmail.com
}

\begin{abstract}
ABSTRAK
Pesatnya pembangunan perlu diantisipasi dengan penataan ruang yang baik dengan memperhatikan ruang terbuka hijau (RTH) sebagai kontrol agar kualitas lingkungan hidup terjaga dengan baik. Dasar penelitian ini dilakukan antara lain karena pembangunan yang terus dilakukan oleh Politeknik Negeri Jakarta (PNJ) yang mengakibatkan semakin berkurangnya RTH serta belum adanya kajian mengenai analisis keberadaan RTH di lingkungan kampus PNJ. Penelitian ini bertujuan untuk menganalisis luas total lahan, luas RTH, nilai koefisien daerah hijau $(\mathrm{KDH})$ di lingkungan kampus PNJ dan menganalisis nilai KDH tersebut dengan ketentuan persyaratan peraturan yang berlaku. Metode yang digunakan dalam penelitian ini yaitu dengan pengukuran langsung luas lahan keseluruhan lingkungan kampus PNJ kemudian hasil pengukuran tersebut diklasifikasikan berdasarkan jenis penggunaan lahan untuk mengetahui luas RTH yang masih tersedia. Berdasarkan hasil pengukuran, luas lahan keseluruhan lingkungan kampus PNJ adalah 11,05 hektar dan luas RTH yaitu seluas 4,4 hektar. Nilai KDH yang didapatkan dari perbandingan antara luas RTH dengan luas lahan keseluruhan yaitu sebesar 39,61\% yang berarti masih di atas syarat minimum yang ditentukan yaitu sebesar $20 \%$. Nilai tersebut harus tetap dipertahankan agar terciptanya keseimbangan antara pembangunan dengan lingkungan hidup.
\end{abstract}

Kata kunci: ruang terbuka hijau, penataan ruang, koefisien daerah hijau

\begin{abstract}
The rapid development needs to be anticipated by good spatial planning by paying attention to green open space (RTH) as a control so that the quality of the environment is well maintained. The basis of this study was carried out, among others, because the ongoing development of the Jakarta State Polytechnic (PNJ) resulted in a reduction in green open space and the absence of studies on the analysis of green open space in PNJ campus environments. This study aims to analyze the total land area, RTH area, green area coefficient value $(K D H)$ in PNJ campus environment and analyze the value of the KDH with the provisions of the applicable regulatory requirements. The method used in this research is by measuring the land area of the entire PNJ campus environment then the measurement results are classified based on the type of land use to find out the area of open green space that is still available. Based on the measurement results, the total land area of the PNJ campus is 11.05 hectares and the area of green space is 4.4 hectares. The value of $K D H$ obtained from the comparison between the area of green space and the total land area is equal to $39.61 \%$ which means that it is still above the specified minimum requirement of 20\%. This value must be maintained in order to create a balance between development and the environment.
\end{abstract}

Keywords: green open space, spatial planning, green area coefficien 


\section{PENDAHULUAN}

Pembangunan harus memperhatikan penataan ruang agar terciptanya keseimbangan antara lingkungan alam dan lingkungan binaan yang berguna untuk kepentingan masyarakat. Penataan ruang menjadi dasar untuk mengantisipasi pesatnya pembangunan yang harus diikuti dengan kebijakan penyediaan ruang terbuka hijau (Samsudi, 2010). Ruang terbuka hijau (RTH) sebagai bagian dari penataan ruang menjadi pemegang kontrol penting terhadap pesatnya pembangunan.

Seiring dengan banyaknya jumlah mahasiswa dan padatnya kegiatan perkuliahan yang membutuhkan sarana dan prasarana, PNJ terus mendirikan bangunan sementara luas lahan keseluruhan PNJ tidak bertambah. PNJ yang berada di Kota Depok harus memenuhi persyaratan peraturan yang berlaku yaitu Peraturan Daerah Kota Depok Nomor 1 Tahun 2015 Tentang Rencana Tata Ruang Wilayah Kota Depok Tahun 2012 2032 yang mensyaratkan zonasi dengan kepadatan tinggi minimal harus menyediakan 20 persen dari luas lahan keseluruhan untuk RTH.

\section{PERUMUSAN MASALAH}

1. Berapa luas RTH dan nilai koefisen daerah hijau di lingkungan kampus PNJ

2. Apakah RTH yang ada di PNJ masih memenuhi persyaratan Peraturan Daerah Kota Depok Nomor 1 Tahun 2015 Tentang Rencana Tata Ruang Wilayah Kota Depok

\section{TINJAUAN PUSTAKA}

\section{Penataan Ruang}

Undang-Undang Nomor 26 Tahun 2007 mengartikan penataan ruang sebagai suatu sistem proses perencanaan tata ruang, pemanfaatan ruang dan pengendalian pemanfaatan ruang. Perencanaan tata ruang adalah suatu proses untuk menentukan struktur ruang dan pola ruang yang meliputi penyusunan dan penetapan rencana tata ruang. Pemanfaatan ruang adalah upaya untuk mewujudkan struktur ruang dan pola ruang sesuai dengan rencana tata ruang melalui penyusunan dan pelaksanaan program beserta pembiayaannya. Pengendalian pemanfaatan ruang adalah upaya untuk mewujudkan tertib tata ruang.

\section{Ruang Terbuka Hijau}

Ruang terbuka terdiri atas RTH dan ruang terbuka nonhijau (RTNH). RTH adalah area memanjang/jalur dan/atau mengelompok, yang penggunaannya lebih bersifat terbuka, tempat tumbuh tanaman, baik yang tumbuh secara alamiah maupun yang sengaja ditanam (Undang-Undang Nomor 26 tahun 2007). RTNH adalah ruang terbuka di wilayah perkotaan yang tidak termasuk dalam kategori RTH, berupa lahan yang diperkeras maupun yang berupa badan air. RTNH selanjutnya dapat dibagi menjadi ruang terbuka perkerasan (paved), ruang terbuka biru (badan air) serta ruang terbuka kondisi tertentu lainnya (Peraturan Menteri Pekerjaan Umum Nomor 12 Tahun 2009). Secara singkat pengertian ruang terbuka ialah ruang yang berada di luar bangunan. Definisi RTH ialah ruang terbuka yang dapat ditumbuhi tanaman. Sedangkan pengertian RTNH ialah ruang terbuka yang tidak termasuk dalam kategori RTH seperti lahan yang diperkeras maupun yang berupa badan air. 
Berdasarkan Peraturan Menteri Nomor 5 Tahun 2008, secara fisik RTH terbagi menjadi RTH alami berupa habitat liar alami, kawasan lindung dan taman-taman nasional serta RTH nonalami atau binaan seperti taman, lapangan olahraga berumput yang dapat menyerap air, pemakaman dan jalur hijau jalan. Sedangkan dalam Peraturan Menteri Pekerjaan Umum Nomor 12 Tahun 2009, RTNH diklasifikasikan menjadi ruang terbuka perkerasan dan ruang terbuka biru. Ruang terbuka perkerasan terdiri dari plasa, parkir, lapangan olahraga perkerasan, tempat bermain dan rekreasi, pembatas (buffer) dan koridor. Plasa merupakan suatu bentuk RTNH sebagai suatu pelataran tempat berkumpulnya massa (assembly point) dengan berbagai jenis kegiatan. Parkir merupakan suatu bentuk RTNH yang memiliki fungsi ekonomis yang berfungsi sebagai pelataran untuk meletakkan kendaraan. Lapangan olahraga pada RTNH ini merupakan pelataran yang diperkeras tempat dilangsungkannya kegiatan olahraga seperti badminton, basket dan voli. Tempat bermain dan rekreasi merupakan pelataran dengan berbagai kelengkapan tertentu untuk mewadahi kegiatan utama bermain atau rekreasi masyarakat. Pembatas (buffer) merupakan suatu jalur dengan fungsi utama sebagai pembatas yang menegaskan peralihan antara suatu fungsi dengan fungsi lainnya seperti median jalan. Koridor merupakan jalur dengan fungsi utama sebagai sarana aksesibilitas pejalan kaki yang bukan merupakan trotoar. Sedangkan ruang terbuka biru terdiri dari waduk, bendungan, kanal dan polder. Ruang terbuka biru ini berfungsi untuk menerima limpasan air hujan yang tidak dapat terserap langsung oleh tanah yang dikumpulkan sementara kemudian diresapkan ke dalam tanah atau dialirkan ke sungai sekitar atau laut. Ketentuan ruang terbuka biru lebih lanjut diatur secara terpisah oleh Direktorat Jenderal Sumber Daya Air.

Penyediaan RTH pada suatu daerah mengacu pada syarat nilai KDH yang ada pada rencana tata ruang wilayah tersebut. $\mathrm{KDH}$ adalah angka persentase perbandingan antara luas seluruh ruang terbuka di luar bangunan gedung yang diperuntukkan bagi pertamanan/penghijauan dan luas tanah perpetakan/daerah perencanan yang dikuasai sesuai rencana tata ruang dan rencana tata bangunan dan lingkungan.

\section{Tujuan, Fungsi dan Manfaat Ruang Terbuka Hijau}

Menurut Peraturan Menteri Pekerjaan Umum Nomor 05 Tahun 2008, tujuan penyelenggaraan RTH adalah menjaga ketersediaan lahan sebagai kawasan resapan air, menciptakan aspek planologis perkotaan melalui keseimbangan antara lingkungan alam dan lingkungan binaan yang berguna untuk kepentingan masyarakat, meningkatkan keserasian lingkungan perkotaan sebagai sarana pengaman lingkungan perkotaan yang aman, nyaman, segar, indah, dan bersih.

\section{METODE PENELITIAN}

Penelitian ini dilakukan di lingkungan kampus PNJ Jl. Prof. Dr. G.A Siwabessy, Kampus Universitas Indonesia (UI) Depok pada bulan Februari sampai dengan April 2018. Obyek penelitian ini yaitu RTH yang ada di PNJ.

Jenis data pada penelitian ini yaitu data primer dan data sekunder. Data primer berupa data hasil pengukuran luas lahan keseluruhan yang meliputi luas taman luas sarana dan prasarana serta luas bangunan lainnya di lingkungan kampus PNJ dan melakukan wawancara kepada Dinas Pekerjaan Umum dan Penataan Ruang untuk mendukung 
penelitian. Data sekunder pada penelitian ini berupa data lokasi dan luas lahan yang didapatkan dari PNJ.

Data primer didapatkan dari pengukuran langsung kondisi sebenarnya dengan alat bantu laser distance meter. Data yang telah dikumpulkan tersebut kemudian diolah dan dianalisis lebih lanjut. Analisis data yang dilakukan yaitu analisis luas lahan di lingkungan kampus PNJ, analisis luas RTH dan nilai KDH di lingkungan kampus PNJ. Analisis luas lahan merupakan analisis perhitungan luas lahan yang ada di lingkungan kampus PNJ berdasarkan hasil pengukuran luas lahan berupa luas bangunan, selasar, paving block, kolam, perkerasan jalan, saluran, taman dan lahan terbuka hijau.

Analisis luas RTH merupakan analisis perhitungan luas total lahan dikurangi dengan luas yang terbangun. Analisis $\mathrm{KDH}$ merupakan analisis mengenai perbandingan luas RTH dengan luas total lahan yang didapatkan dari perhitungan sebelumnya kemudian nilai KDH yang ada di PNJ dianalisis untuk mengetahui apakah nilai tersebut memenuhi persyaratan Peraturan Daerah Kota Depok Nomor 1 Tahun 2015 Tentang Rencana Tata Ruang Wilayah Kota Depok Tahun 2012 - 2032.

Rumus untuk mencari nilai $\mathrm{KDH}$ adalah sebagai berikut:

$\mathrm{KDH}=\frac{\text { Luas RTH }}{\text { Luas Total Lahan }} x 100 \%$

\section{HASIL DAN PEMBAHASAN}

\section{Analisis}

Luas lahan keseluruhan lingkungan kampus PNJ didapatkan dengan cara mengukur langsung dan mengklasifikasi jenis penggunaan lahan. Klasifikasi penggunaan lahan terdiri dari luas yang terbangun dan luas yang tidak terbangun (ruang terbuka). Ruang terbuka terbagi menjadi RTH dan RTNH. Contoh luas yang terbangun yaitu gedung perkuliahan, kantin, perpustakaan, rektorat, masjid, dan bangunan lainnya. Contoh RTH yaitu lapangan rumput, taman di sekitar gedung perkuliahan dan area hijau lainnya. Contoh RTNH yaitu perkerasan jalan beton, jalan aspal dan lain-lain. Analisis luas lahan keseluruhan ini digunakan untuk analisis luas RTH yang tersedia di lingkungan kampus PNJ.

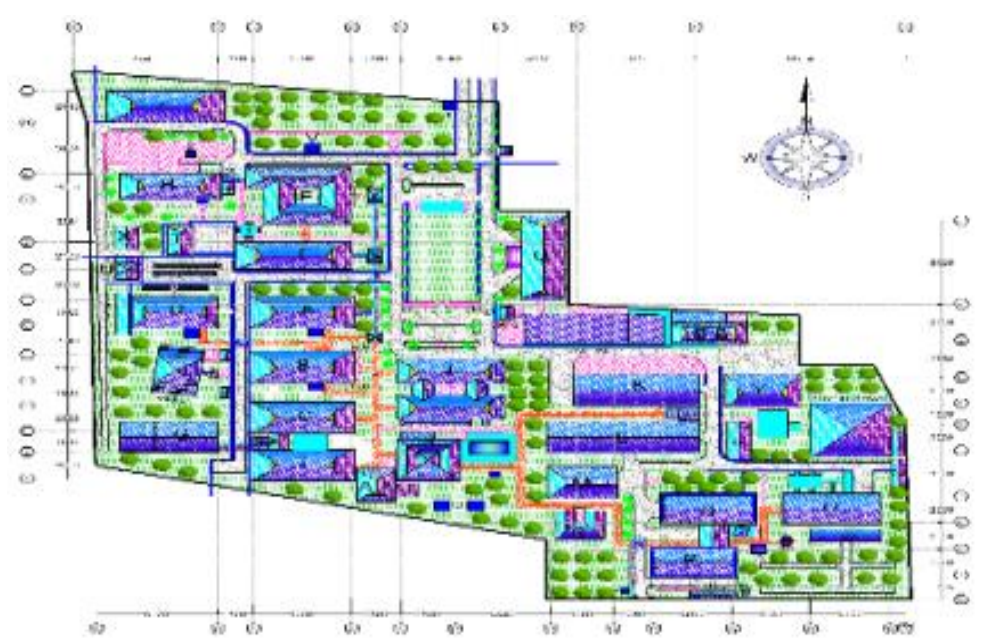

Gambar 1. Site Plan Kampus PNJ Berdasaran Hasil Pengukuran 
Tabel 1. Rekapitulasi Luas Lahan di PNJ

\begin{tabular}{|c|c|c|c|}
\hline & URAIAN & $\operatorname{LUAS}\left(\mathbf{m}^{2}\right)$ & Luas (ha) \\
\hline \multirow[t]{5}{*}{ A. } & Bangunan & & \\
\hline & Gedung bertembok \& tertutup atap & 34176,699 & 3,4177 \\
\hline & Gedung lain-lain bertembok \& tertutup atap & 2336,8655 & 0,2337 \\
\hline & Bangunan tertutup atap \& tidak bertembok & 1179,8564 & 0,1179 \\
\hline & Jumlah & 37693,4209 & 3,7693 \\
\hline \multirow[t]{10}{*}{ B. } & RTNH & & \\
\hline & Selasar beton & 4655,38 & 0,4655 \\
\hline & Selasar genteng metal (GM) & 736,7214 & 0,0736 \\
\hline & Paving block & 5231,864126 & 0,5231 \\
\hline & Lantai beton & 2550,499639 & 0,2550 \\
\hline & Kolom & 216,3438 & 0,0216 \\
\hline & Jalan beton & 1976,12 & 0,1976 \\
\hline & Jalan aspal & 12706,02342 & 1,2706 \\
\hline & Saluran drainase & 940,38385 & 0,0940 \\
\hline & Jumlah & 29013 & 2,9013 \\
\hline \multirow[t]{3}{*}{ C. } & RTH & & \\
\hline & Jumlah & 43761 & 4,3761 \\
\hline & TOTAL Luas Lahan Keselutuhan & 110467,757 & 11,0467 \\
\hline
\end{tabular}

Sumber: Hasil Pengukuran di Lapangan

Untuk memudahkan perhitungan luas lahan keseluruhan berdasarkan hasil pengukuran di lapangan, klasifikasi jenis penggunaan lahan secara rinci yaitu :

\section{Bangunan Gedung Bertembok dan Tertutup Atap}

Merupakan gedung-gedung di PNJ yang beratap dan tinggi dindingnya lebih dari 1.50 meter dari permukaan dasar lantai seluas $34177 \mathrm{~m}^{2}$ atau 3,4177 hektar. Berdasarkan hasil pengukuran, didapatkan luas gedung lain-lain bertembok dan tertutup atap seluas $2336,8655 \mathrm{~m}^{2}$ atau 0,23368 hektar.

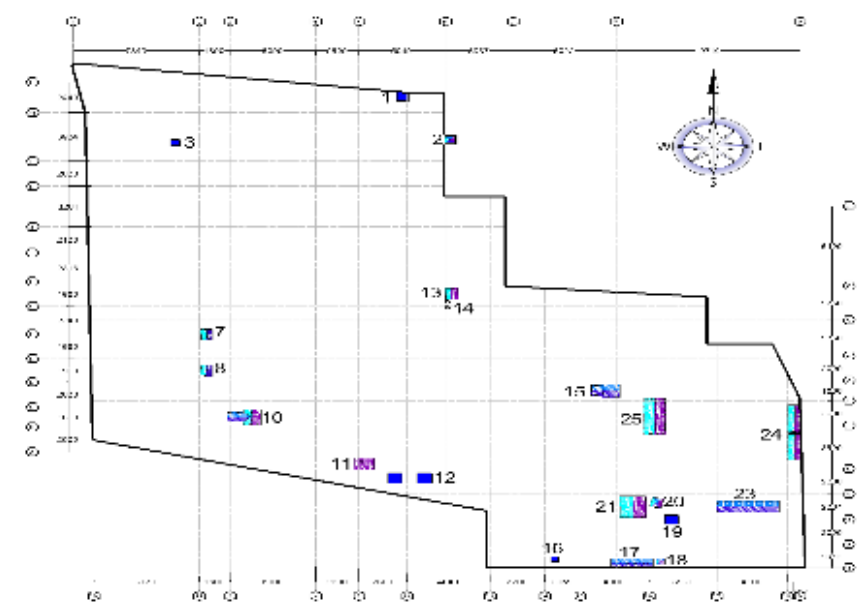

Gambar 2. Site Plan Gedung Lain-lain Bertembok dan Tertutup Atap

\section{Bangunan Lain-lain Tertutup Atap dan Tidak Bertembok}

Bangunan lain-lain tertutup atap dan tidak bertembok adalah bangunan yang tidak diberi nama di PNJ yang beratap dan tinggi dindingnya kurang dari 1.50 meter. Berdasarkan hasil pengukuran, didapatkan luas gedung lain-lain tertutup atap dan tidak bertembok seluas $1179,8564 \mathrm{~m}^{2}$ atau 0,11798 hektar. 


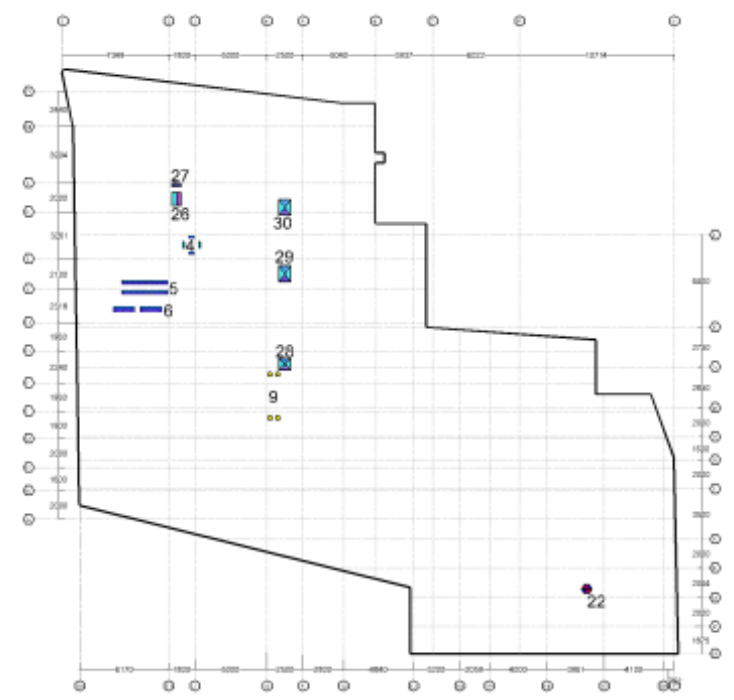

Gambar 3. Bangunan Lain-lain Tertutup Atap dan Tidak Bertembok

\section{Ruang Terbuka Non Hijau}

\section{1) Selasar Beton}

Selasar beton adalah sebuah struktur dengan atap dari beton dan sisi terbuka yang menghubungkan bangunan di PNJ. Contohnya yaitu selasar yang menghubungkan pendopo teknik menuju gedung A, Gedung B, Gedung C, Gedung I, Gedung R, pendopo teknik menuju Gedung D dan masjid, Gedung R menuju workshop teknik sipil dan gedung K. Berdasarkan hasil pengukuran, didapatkan luas selasar beton seluas $4655,38 \mathrm{~m}^{2}$ atau 0,46553 hektar.

\section{2) Selasar Genteng Metal (GM)}

Selasar Genteng Metal (GM) adalah sebuah struktur dengan atap dari genteng metal dan sisi terbuka yang menghubungkan bangunan di PNJ. Berdasarkan hasil pengukuran, didapatkan luas selasar genteng metal seluas $736,7214 \mathrm{~m}^{2}$ atau 0,073672 hektar.

\section{3) Paving Block}

Paving Block adalah bahan bangunan yang dibuat dari campuran semen, air, abu batu, agregat halus dan agregat kasar atau dikenal dengan sebutan concrete block. Paving block digunakan sebagai penutup permukaan tanah. Paving block yang digunakan di lingkungan kampus PNJ tidak dapat menyerap air ke dalam tanah, tidak dapat ditumbuhi tanaman dan pepohonan serta tidak memiliki fungsi sebagai RTH. paving block seluas $5231,86413 \mathrm{~m}^{2}$ atau 0,52318 hektar.

\section{4) Lantai Beton}

Lantai beton digunakan sebagai penutup atau perkerasan permukaan tanah. Lantai beton tidak dapat menyerap air ke dalam tanah, tidak dapat ditumbuhi tanaman dan pepohonan serta tidak memiliki fungsi sebagai RTH. Berdasarkan hasil pengukuran, didapatkan luas lantai beton seluas $2550,4996 \mathrm{~m}^{2}$ atau 0,255049 hektar.

\section{5) Kolam Renang dan Kolam Ikan}

Kolam PNJ tidak dapat menyerap air ke dalam tanah, tidak dapat ditumbuhi tanaman dan pepohonan serta tidak memiliki fungsi sebagai RTH.. Berdasarkan hasil 
pengukuran, didapatkan luas kolam renang dan kolam ikan seluas $216,343 \mathrm{~m}^{2}$ atau 0,02163 hektar.

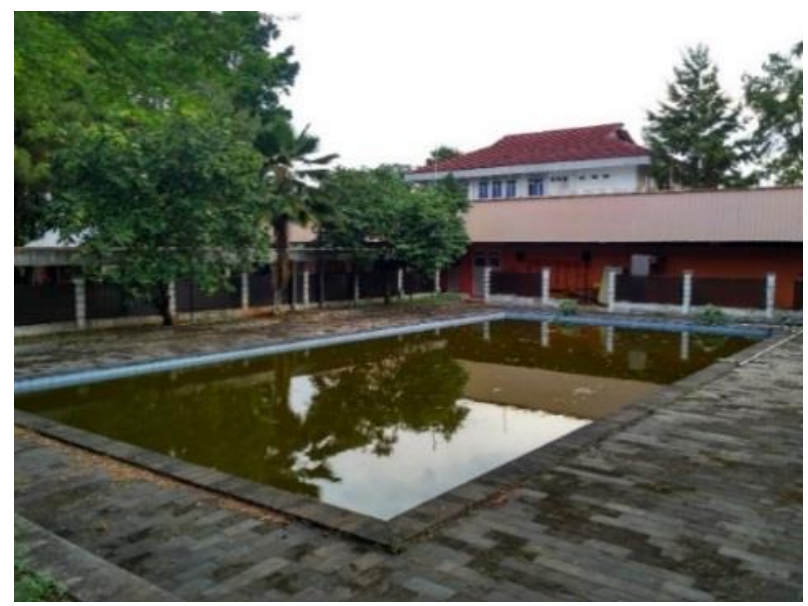

Gambar 4. Kolam PNJ

\section{6) Jalan Beton}

Jalan beton adalah jalan di PNJ yang menggunakan perkerasan kaku (rigid pavement) untuk dilalui kendaraan. Jalan beton tidak dapat menyerap air ke dalam tanah, tidak dapat ditumbuhi tanaman dan pepohonan serta tidak memiliki fungsi sebagai RTH. Penggunaan jalan beton berada di sepanjang jalan dari Gedung $M$ menuju pintu belakang PNJ dan berada di lahan parkir Gedung Y Alat Berat. Berdasarkan hasil pengukuran, didapatkan luas jalan beton seluas 1976,12 $\mathrm{m}^{2}$ atau 0,197612 hektar.

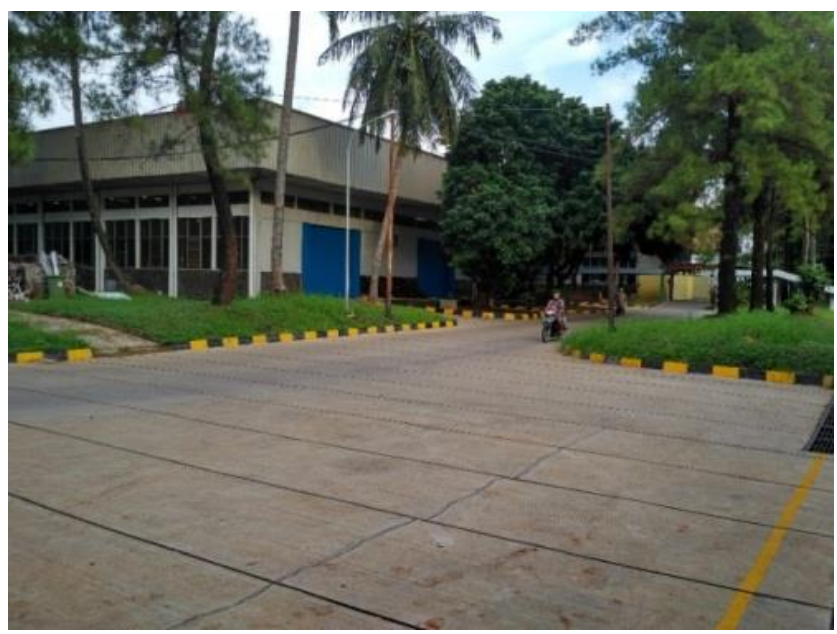

Gambar 5. Jalan Beton di PNJ

\section{7) Jalan Aspal}

Jalan aspal adalah jalan di PNJ yang menggunakan perkerasan lentur (flexible pavement) untuk dilalui kendaraan. Jalan aspal tidak dapat menyerap air ke dalam tanah, tidak dapat ditumbuhi tanaman dan pepohonan serta tidak memiliki fungsi sebagai RTH. Penggunaan jalan aspal berada di sepanjang jalan yang dapat dilalui mobil dari pintu masuk utama menuju gedung perpustakaan baru, sepanjang lapangan utama menuju Gedung $\mathrm{G}$ dan Gedung Z, sepanjang Gedung Z menuju bagian belakang 
Gedung G, berada di area parkir kendaraan dosen PNJ dan berada di area workshop teknik sipil. Berdasarkan hasil pengukuran, didapatkan luas jalan aspal seluas $12706,0234 \mathrm{~m}^{2}$ atau 1,270602 hektar.

\section{8) Saluran Drainase}

Saluran drainase adalah tempat mengalirnya air yang bersumber dari air hujan di PNJ menuju sungai. Drainase tidak dapat menyerap air ke dalam tanah, tidak dapat ditumbuhi tanaman dan pepohonan serta tidak memiliki fungsi sebagai RTH karena menggunakan U-Ditch yang terbuat dari beton precast. Lokasi saluran drainase berada di bagian kanan dan kiri sepanjang jalan aspal yang dapat dilalui mobil. Berdasarkan hasil pengukuran, didapatkan luas saluran drainase yaitu $940,38385 \mathrm{~m}^{2}$ atau 0,094 hektar.

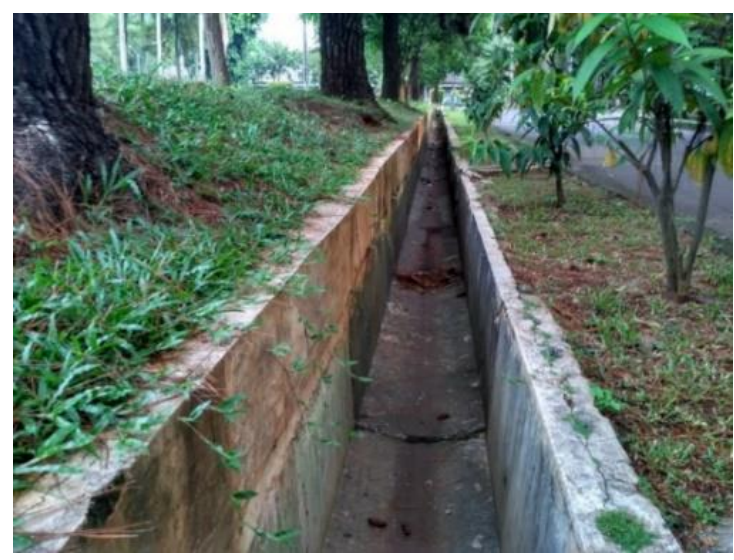

Gambar 6. Saluran Drainase PNJ

Berdasarkan uraian hasil perhitungan maka luas RTNH di lingkungan kampus PNJ yaitu sebesar $66706,7572 \mathrm{~m}^{2}$ atau 6,780675 hektar.

\section{Ruang Terbuka Hijau}

Berdasarkan hasil pengukuran di lapangan, luas RTH yang ada di lingkungan kampus PNJ ialah sebesar $43.761 \mathrm{~m}^{2}$ atau 4,3761 hektar dari luas lahan keseluruhan yaitu sebesar $110.467 \mathrm{~m}^{2}$ atau 11,0467 hektar.

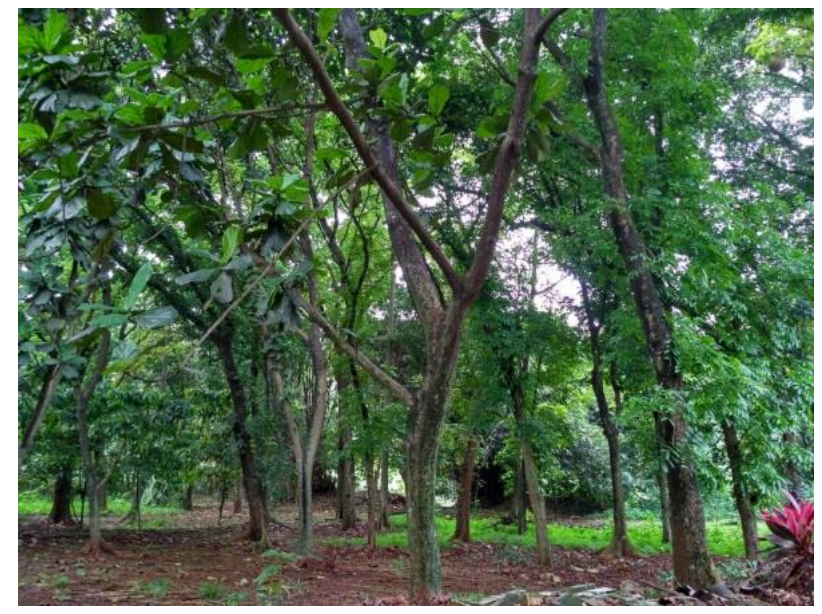

Gambar 7. RTH di PNJ 


\section{Analisis Luas Ruang Terbuka Hijau di Politeknik Negeri Jakarta}

Luas RTH yang ada di lingkungan kampus PNJ diketahui dengan cara mengukur luas lahan keseluruhan dengan mengklasifikasi jenis penggunaan lahan. Penggunaan lahan yang tidak memiliki fungsi sebagai RTH merupakan luas yang terbangun dan RTNH sehingga air tidak dapat menyerap langsung ke dalam tanah.

Peraturan Daerah Kota Depok Nomor 1 Tahun 2015 Tentang Rencana Tata Ruang Wilayah Kota Depok Tahun 2012 - 2032 tidak mengatur syarat KDH untuk kawasan pendidikan secara jelas. Akan tetapi, berdasarkan hasil wawancara dengan pegawai Dinas Pekerjaan Umum dan Penataan Ruang, PNJ yang berada dalam lingkungan Universitas Indonesia dan berada di daerah zonasi dengan kepadatan tinggi yang telah diatur dalam Peraturan Daerah Kota Depok Nomor 1 Tahun 2015 minimal harus menyediakan 20 persen dari luas lahan keseluruhan untuk RTH dan koefisien dasar bangunan (KDB) paling besar 75 persen. Berdasarkan acuan tersebut, PNJ yang memiliki luas sebesar $110.467 \mathrm{~m}^{2}$ atau 11,0467 hektar harus menyediakan RTH paling sedikit seluas 22.093,4 $\mathrm{m}^{2}$ atau 2,20934 hektar.

Rumus untuk mendapatkan nilai KDH (Persamaan 1):

$\mathrm{KDH}$ di PNJ $=\frac{43761}{110467} \times 100 \%$

$\mathrm{KDH}$ di $\mathrm{PNJ}=39,61 \%$

Jika standar RTH berdasarkan Peraturan Daerah Kota Depok Nomor 1 Tahun 2015 dibandingkan dengan kondisi RTH yang ada sekarang maka PNJ masih mempunyai RTH yang cukup yakni seluas $43.761 \mathrm{~m}^{2}$ atau 4,3761 hektar $(39,61 \%)$ dari batas minimal yaitu 22.093,4 $\mathrm{m}^{2}$ atau 2,20934 hektar.

\section{$\underline{\text { Pembahasan }}$}

\section{Ruang Terbuka Hijau}

Berdasarkan hasil pengukuran di lapangan, luas RTH yang ada di lingkungan kampus PNJ ialah sebesar $43.761 \mathrm{~m}^{2}$ atau 4,3761 hektar dari luas lahan keseluruhan yaitu sebesar $110.467 \mathrm{~m}^{2}$ atau 11,0467 hektar. Lahan yang ada pada saat ini sangat rawan terhadap perubahan status alih fungsi lahan dikarenakan banyaknya kegiatan perkuliahan yang membutuhkan pembangunan sarana dan prasarana sehingga secara tidak langsung mengakibatkan berkurangnya luas lahan untuk RTH. Lahan hijau yang ada di lingkungan kampus PNJ membentuk pola menyebar. Vegetasi yang ada di dalamnya pun cukup bervariasi seperti pohon beringin, mahoni, trembesi, pinus, tanjung, trembesi, palem raja, kenari, matoa, rambutan, manga, jambu air, semak, rumput dan lain-lain.

\section{Pengembangan Ruang Terbuka Hijau di Politeknik Negeri Jakarta}

Pengembangan ini dimaksudkan sebagai saran untuk meningkatkan kuantitas dan kualitas RTH agar diperoleh manfaat yang sebesar-besarnya. Upaya yang dapat dilakukan yaitu peremajaan pohon-pohon yang berdiameter besar. Menurut Keputusan 
Direktorat Jenderal Kehutanan No. 35/Kpts/DD/I/1972 tentang Pedoman Tebang Pilih Indonesia, ukuran pohon yang dapat ditebang mempunyai diameter minimum sebesar $50 \mathrm{~cm}$ dan dilakukan penanaman kembali dengan memilih jenis vegetasi sesuai dengan kriteria berdasarkan Peraturan Menteri Pekerjaan Umum Nomor 5 Tahun 2008.

\section{KESIMPULAN DAN SARAN}

\section{Kesimpulan}

Dari hasil analisis dan pembahasan yang telah dilakukan maka didapatkan kesimpulan sebagai berikut:

1. Luas RTH yang ada di lingkungan kampus PNJ yaitu seluas 4,3761 hektar. Nilai $\mathrm{KDH}$ yang didapatkan sebesar 39,61\%.

2. Luas RTH $(39,61 \%)$ yang ada di PNJ tersebut masih memenuhi syarat berdasarkan Peraturan Daerah Kota Depok Nomor 1 Tahun 2015 yaitu sebesar 20\%.

\section{Saran}

1. Luas RTH yang ada sekarang sebaiknya dijaga keberadaannya dan nilai KDH yang ada juga dipertahankan. Agar tercipta suasana yang sejuk, indah dan asri untuk mendukung kegiatan perkuliahan, upaya yang dapat dilakukan dalam pengembangan RTH di PNJ yaitu peremajaan pohon yang berdiameter lebih dari 50 cm untuk menghindari

2. pohon tumbang karena sudah tua dan penambahan pohon dengan memilih jenis vegetasi berdasarkan kriteria pada Peraturan Menteri Pekerjaan Umum Nomor 5 Tahun 2008.

3. Pengembangan bangunan ke depannya sebaiknya diarahkan secara vertikal agar tidak mengganggu keberadaan RTH yang ada saat ini.

\section{DAFTAR PUSTAKA}

[1] Anonim. 2007. Undang-Undang nomor 26 tentang Penataan Ruang. Jakarta: Direktorat Jenderal Penataan Ruang.

[2] Departemen Pekerjaan Umum. 2008. Peraturan Menteri Pekerjaan Umum Nomor:05/PRT/M/2008 tentang Pedoman Penyediaan dan Pemanfaatan Ruang Terbuka Hijau di Kawasan Perkotaan. Jakarta: Direktorat Jenderal Penataan Ruang.

[3] Departemen Pekerjaan Umum. 2008. Peraturan Menteri Pekerjaan Umum Nomor:12/PRT/M/2009 tentang Pedoman Penyediaan dan Pemanfaatan Ruang Terbuka Nonhijau di Kawasan Perkotaan. Jakarta: Direktorat Jenderal Penataan Ruang.

[4] Departemen Dalam Negeri. 1988. Instruksi Menteri Dalam Negeri Nomor 14 Tahun 1988 tentang Penataan Ruang Terbuka Hijau di Wilayah Perkotaan. Jakarta: Departemen Dalam Negeri.

[5] Samsudi. 2010. "Ruang Terbuka Hijau Kebutuhan Tata Ruang Perkotaan Kota Surakarta" dalam Journal of Rural and Development. Solo: Universitas Sebelas Maret.

[6] Sinulingga, B.D. 2005. Pembangunan Kota. Jakarta: Pustaka Sinar Harapan. 